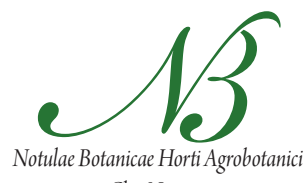

Cluj-Napoca

\title{
Forest Monitoring - Assessment, Analysis and Warning System for Forest Ecosystem Status
}

\author{
Ovidiu BADEA ${ }^{1,2}$, Diana SILAGHI ${ }^{1,2 *}$, Ioan TAUT ${ }^{1,3}$, Stefan NEAGU'1, Stefan LECA ${ }^{1,2}$ \\ ${ }^{1}$ Forest Research and Management Institute, Eroilor Bld. 128, 77190 Voluntari, Ilfor, Romania; badea63@yahoo. \\ com,dianasilaghi@ymail.com (*correspondingauthor),stefanneagu@yahoo.com,leca_d_stefan@yahoo.com \\ ${ }^{2}$ Transilvania University of Brasov, Faculty of Silviculture and Forest Engineering, 500068, Brasov, Romania \\ ${ }^{3}$ University of Agricultural Science and Veterinary Medicine, Cluj-Napoca, Calea Mănăşstur \\ 3-5 Str., 400372, Cluj-Napoca, Romania; ioan_taut90@yahoo.com
}

\begin{abstract}
Forests provide essential benefits and services as an important component of terrestrial ecosystems. Their functionality and health result from multiple and cumulative interactions of biotic and abiotic stress factors such as air pollution, climate change, changes in land use, and poor management practices. A forest monitoring system was established to identify, analyze and assess the degradation of European forests. Two levels of forest monitoring were developed: I) large-scale forest condition surveys, based on an European grid system starting in 1986 and II) an intensive non-systematic survey network placed in representative forest ecosystems starting in 1994. Romania implemented both level I (1990-1991) and level II (1991-1992) forest monitoring surveys with the results showing the effects of increased air temperatures and a drastic decrease of precipitation since the decade of 1971-1980. Thus, the highest values of damaged trees (crown defoliation >25\%) percent were recorded in 1993, 1994, 2000 and 2003 both in the national and European networks. Also, in southern and South-Eastern Romania the forests are more frequently damaged as a response to worsening of climatic factors in this region in recent decades, with temperatures rising $0.7-0.8^{\circ} \mathrm{C}$. In general, in Romania, ozone concentrations remained below the critical threshold $(40-50 \mathrm{ppb})$ for affecting growth or health of trees. The levels of $\mathrm{S}-\mathrm{SO}_{4}$ and $\mathrm{N}-\mathrm{NO}_{3}$ declined in the atmosphere but the accumulation continued to increase in the soil, leading to soil acidification, mainly at depths of $10-40 \mathrm{~cm})$. In general, during the last decade, Romanian forests were affected at low to medium intensities with damage rate up to $11 \%$ of the trees and the status of general forest health improved slightly.
\end{abstract}

Keywords: air pollution, climate change, crown condition, forest monitoring, national and transnational network

\section{Introduction}

Forests exhibit the highest levels of biodiversity of all types of ecosystems, providing habitats for a wide range of animal and plant species. With their considerable potential for carbon sequestration, they constitute one of the most important elements of the global carbon cycle. In addition to their great importance to the earth's climate and biodiversity, forests play a significant role in the development of rural areas and provide many recreational opportunities for people as well as protective functions for soil, water and infrastructure and contribute goods and services to the economic sector (Badea et al., 2005).

The decline of forest ecosystems health, reported in the early 1980s and highlighted through research undertaken at international level (Vins and Mrkva, 1973; Symeonides, 1979; Thompson, 1981; Lorenz, 1991; Giurgiu, 1979, 1988; Ianculescu, 1990) has been mainly caused by the interaction of atmospheric pollution and various biotic and abiotic factors as well as other disturbances, such as anthropogenic disturbances or fires. The results obtained from these studies clearly demonstrated pollutants and other stress factors have had a negative influence on forest growth and in many cases caused an abnormal dieback of trees and declines in forested ecosystems as a whole. Also, multiple cumulative effects have had a considerable influence on the status of forest ecosystems at local, regional and global scales. Major consequences of the changes in forested ecosystems include the rapid shifting of vegetation boundaries toward higher altitudes, increases in the intensity of processes which are damaging the trees, increases in tree mortality and declines of other ecosystem parameters, all of which pose threats to ecosystem biodiversity and forest habitats.

In response to these events and conditions and based on the United Nations Economic Commission for Europe's (UNECE) Convention on Long-range Transboundary Air Pollution (UN/ECE 1979), in United States, Canada and in almost all European countries, concerns regarding research and long-term monitoring of forested ecosystems experiencing the effects of these various stress factors, especially air pollution, have intensified.

To identify, analyze and monitor the degradation and disruption of forested ecosystems across Europe, forest- 
614

ers and forest scientists have developed specific methods and procedures for continuous monitoring of the factors which influence the quality of forested ecosystems and specifically across Europe, the forest monitoring system. The main objectives of forest monitoring are: (i) implementing of priority actions included in policies and strategies designed to protect forests against the impacts of air pollution, climate change and other biotic and abiotic stress factors; (ii) improving the coordination and integration of forest monitoring activities to assist land managers in assessing the vulnerability and adaptive capabilities of forest vegetation under the combined effects of climate change and air pollution; (iii) harmonizing forest monitoring methodologies used at national and European levels; (iv) providing information for criteria and indicators for sustainable forest management as defined by the Ministerial Conference on the Protection of Forests in Europe; (v) highlighting the effects of climate change, air pollution and other stress factors on forest status and biodiversity, by means of annual reports documenting critical events identified at local, regional and European levels, and (vi) creating a common database on forest status at national and European levels.

The successful implementation of the protocols regarding the control of pollutant emissions by the CLRTAP signatory countries and of special monitoring programs (ICP-Forests, European Union (EU) Scheme, Forest Focus Scheme and LIFE+) has led to a significant reduction of industrial pollution in most European countries in the last few decades, and also led to the establishment of a well-organized trans-disciplinary monitoring system of forest ecosystems and efforts to determine the effects of the main factors disrupting forested ecosystems, especially air pollution and climate changes.

One of the most important achievements of the European Forest Monitoring System is the development of specific, well-developed and uniform indicators and criteria related to forest health, as well as the development of common forest monitoring methodologies. Their uniform application allows the comparison of results and the development of long-term data series. Currently, atmospheric pollution and pollutant depositions in forests and forest soils continues to be an important issue, while nitrate deposition is still a serious threat because of its effects on forest ecosystems (Thimonier et al., 2010). The increasing ozone concentrations (Volz and Kley, 1988; Fowler et al., 1999) combined with a decline in biodiversity and basic changes in the environment are processes that produce significant changes at the global level, such as the increase in mean air temperatures as well as an increase in the frequency of extreme weather events, drought, and other catastrophic weather related phenomena (IPCC, 2007; Jentsch et al., 2007; Sterl et al., 2008). Limited water availability can affect either forests as a whole or individual trees. Singular events, like extreme drought or heat waves such as the ones which occurred during the summer of 2003 (Stott et al.,
2004; Ciais et al., 2005), can cause declines in tree growth (Piovesan et al., 2008; Granier et al., 2007), high levels of tree mortality (Carnicer et al., 2011; Allen et al., 2010) and other delayed multiannual effects (Bigler $e$ t al., 2007). Also, limited water availability is considered the most serious threat for forests at a global scale (Allen and Breshears, 1998). Predictions on the evolution of climate can be made using specific modeling procedures.

Assuring the persistence of high levels of biodiversity in forested ecosystems is widely acknowledged to be the best way to guarantee that forests will be capable of adapting to present and future climatic changes (Lindner et al., 2010). Knowing the existence of these threats, there has been a consistent preoccupation at the international level for maintaining forest health so as to conserve forests, to promote sustainable management of forests and to enhance forest functions by maintaining a high level scientific information, which can be obtained in the well-organized system used to monitor the European forests.

\section{Monitoring networks and methods}

From its infancy in 1985, the main causes of declines in forest ecosystems were high concentrations of sulfur $(S)$ and related compounds, which determined the occurrence of acid rain and subsequently, the intensification of soil acidification. These alarming processes and signals had highlighted the need to develop a strategic policy regarding atmospheric pollution. All these actions were implemented under the UNECE-CLRTAP program and under the EU policies related to "clean air," and resulted in a greater than $70 \%$ reduction in sulfur deposition. Since 1985, the International Co-operative Programme on Assessment and Monitoring of Air Pollution Effects on Forests (ICP-Forests) can be credited with providing a considerable share of the effort needed to highlight these actions, through providing scientific information. This program has been providing regular updates on the condition of forests in Europe for over 27 years. Since 1986, after its first year of operation, the ICP-Forests program has been cooperating with the European Union (EU). Initially, this cooperation was based on the EU Scheme (EC Regulation No. 3528/1986) and Forest Focus Regulation (EC No. 2152/2003). The last of these regulations constituted the legal basis for the co-financing of forest monitoring activities, which continued until 2006. Since then, the Regulation (614/2007) "LIFE+" has provided the legal basis for co-financing of the future development of forest monitoring at the European level (Fig. 1). The main purpose of the large-scale forest monitoring (level I) is to assess the dynamics and spatial distribution of tree damage and to analyze long term data series related to forest health status and vitality. At the European level, 7,500 permanent and representative plots within a $16 \times 16 \mathrm{~km}$ grid system 
(herein called the European grid system) have been used for annual data collection.

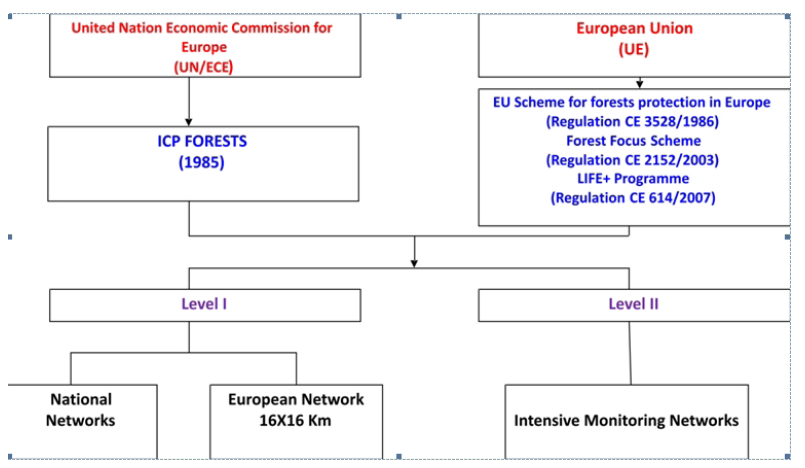

Fig. 1. Functioning of forest monitoring at the European level (European grid system)

To determine the influence of various stress factors on forest ecosystem status and to better understand interactions between these plots as well as their cumulative changes, 500 monitoring plots were designated for intensive, permanent and continuous data collection.

Over the years, a two-level survey system has been developed: level I refers especially to general information gathering related to annual forest health status, while level II refers to intensive scientific research in representative forest ecosystems. Furthermore, most of the European countries are monitoring their forest resources at the national level, using specific methodologies.

In Romania, during 1990-2006, level I monitoring has consisted of a mixed network, having two roles: (i) monitoring of forest ecosystem health and (ii) performing a National Forest Inventory, although the network has been abandoned because of the lack of financing.

The negative impact of environmental factors on forests was similar in Romania to what has been described as occurring in most European countries, where damaged forests and those with abnormal dieback were becoming progressively predominant until the 1980s; the assessment of the status of certain factors (including forest health) had seen conducted using non-systematic methods at that time. These monitoring methods were focused on (i) the revision of forest management plans every 10 years, (ii) the initial forest inventories based on those management plans, and (iii) the specific research and studies. These methods were deficient due to the fact that (i) the information gathered was insufficient because it came from different sources and was collected using different methods, and (ii) the information was recorded at different points in time. To improve this situation, the development of a single, uniform forest survey system for both national and European levels was initiated. In 1990, this system and concept was adopted and correlated with the one applied by the member countries of ICP-Forests and was the applied across the entire Romanian forestry system (Or- der No. 96/1990 of the Deputy Minister of Silviculture; Badea and Patrascoiu, 1998) (Fig. 2).

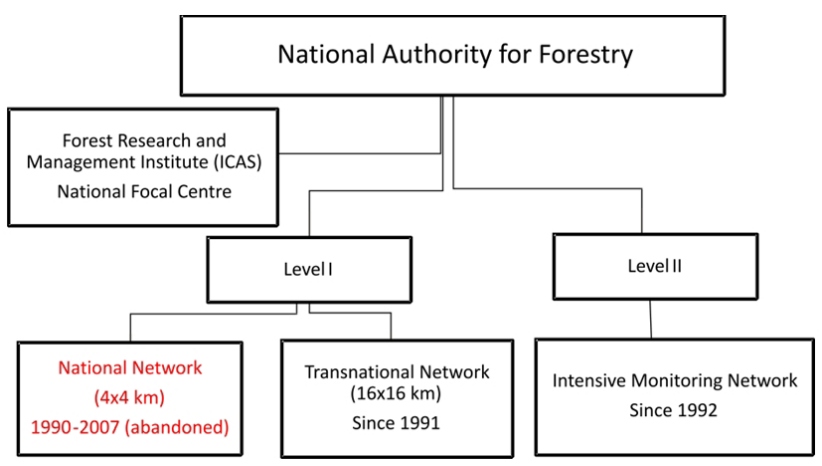

Fig. 2. Functioning of forest monitoring system in Romania (national grid system)

The survey system was developed and improved when the "Regulation of the Organization and Functioning of Forest Monitoring in Romania" was applied (Order No. 249/1994 of Minister of Water, Forests and Environmental Protection). In 2002, a special law related to forest monitoring was adopted (Law No. 444/2002) followed by the Governmental Decision No. 1003/2003 related to the functioning and financing of forest monitoring in Romania. As in all ICP-Forests European member countries, forest monitoring activity was carried out at a large scale; the forest condition surveys were based on a permanent national $(2 \times 2 \mathrm{~km}$ and $2 \times 4 \mathrm{~km})$ and European grid system plots (level I) (Fig. 3a) and on intensive plots placed in representative forest ecosystems within a nonsystematic network (level II) (Fig. 3b). Additionally, in Romania, long term ecological research was developed in two LTER sites (Retezat and Bucegi - Piatra Craiului) (Badea et al., 2011).

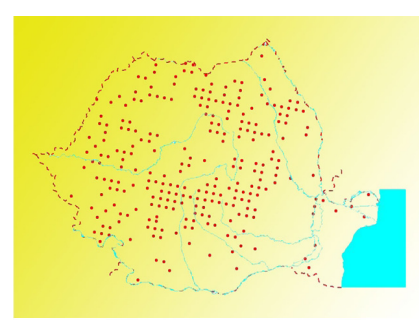

(a)

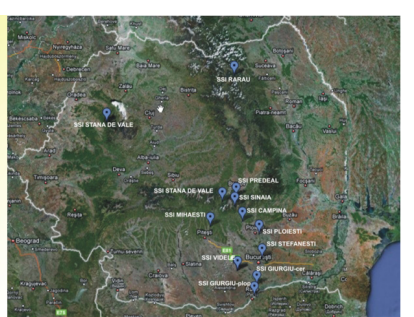

(b)
Fig. 3. Romanian ICP-Forests Large Scale European grid system network (a) $(16 \times 16 \mathrm{~km}$; (252 permanent plots) and intensive monitoring network (b): 12 permanent plots in representative forest ecosystems in place since 1992

The Romanian forest survey through the national permanent plot network $(2 \times 2$ and $2 \times 4 \mathrm{~km})$ was based on: (i) annual records including information on the status of tree crowns and damage caused by different factors (e.g. biotic, abiotic, anthropogenic, pollution or fires); (ii) periodical records collected every 5 years related to the devel- 
616

opment of a National Forest Inventory (NFI), regarding the status and evolution of the primary parameters related to forest condition assessment and measures of the forests capacity to fulfill socio-economic services at both national and international levels.

To assess tree crown condition and mechanical damage, 30 (15 in every permanent subplot-PSP) predominant, dominant and co-dominant trees were initially chosen in every plot (Fig. 4), representing trees with moderate to strong mechanical damages (Patrascoiu and Badea, 1990).

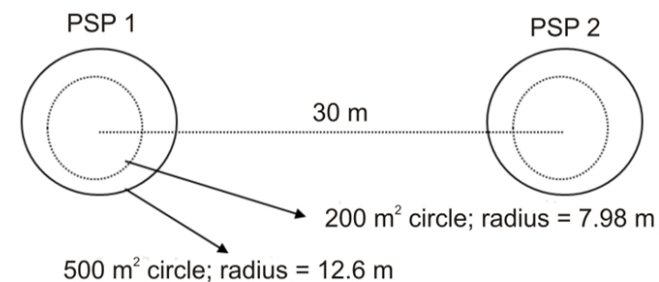

Fig. 4. Design of a national forest monitoring plot

Until 2006, for these 30 trees, defoliation and discoloration were evaluated annually (UN/ECE 1989, 2004) and the presence of the damage caused by abiotic factors (wind, snow, frosts), biotic factors (game, insects, fungi) and anthropogenic factors (e.g. pollution, fires) were observed.

Beginning with 2007, this national forest monitoring network consisting of the $2 \times 2$ and $2 \times 4 \mathrm{~km}$ grid systems was abandoned and the assessment of crown condition has focused on the European grid system only, which included 252 plots in Romania, based on the geographical coordinates received from the ICP-Forests program (Program Coordinating Centre, Hamburg, Germany). This was done using the methodology adopted by the participating countries in the ICP-Forests and in the European Union scheme (EU Scheme).

Each permanent sample plot (PSP) contains four subplots placed crosswise on the direction of cardinal points, at $25 \mathrm{~m}$ from the plot's center. Each subplot includes the six trees closest to its center (Fig. 5). Compared with the national network, the number of trees evaluated annually in the European grid system is constant (24). Any trees which had been damaged by being broken or have been removed (cut) are replaced by others during the annual evaluation (UN/ECE, 1989; Badea and Patrascoiu, 1992).

This transnational network has been also designated for the assessment of soil conditions every 10 years. Annual results related to crown condition from both the national and transnational plot networks are reported and included in the Annual Reports on Forest Condition in Europe, developed by the ICP-Forests program.

Because of the very high number of trees assessed in the national network, Romania has made a consistent contribution at the European level between 1990 and 2006
(UN/ECE 1991-1998). Since 1998, after statistical optimization of the national network, the number of plots and trees assessed were reduced by a factor of four $(4 \times 4 \mathrm{~km})$ (Badea, 1998).

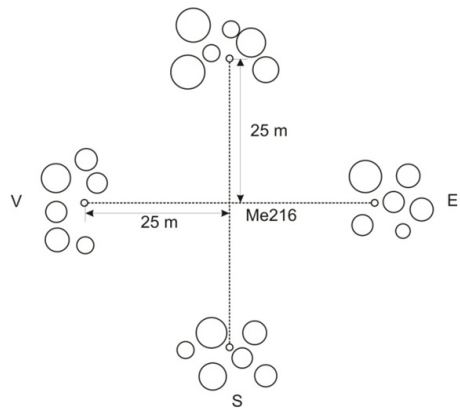

Fig. 5. Design of a forest monitoring level I plot $(16 \times 16 \mathrm{~km}$ European grid system)

In 2010, in the framework of the LIFE+ Further Development and Implementation of an EU-level Forest Monitoring (FutMon) project, a large scale systematic crown condition monitoring network was created by placing a southeastern plot of the NFI tract in the center of the former European level I plots (Fig. 6). For this purpose, over 20 years of data on crown condition assessment at level I are available, and starting with 2010, this database has been includind information specific to NFI, which can be useful, comparable, and compatible at the European grid system $(16 \times 16 \mathrm{~km})$ scale.

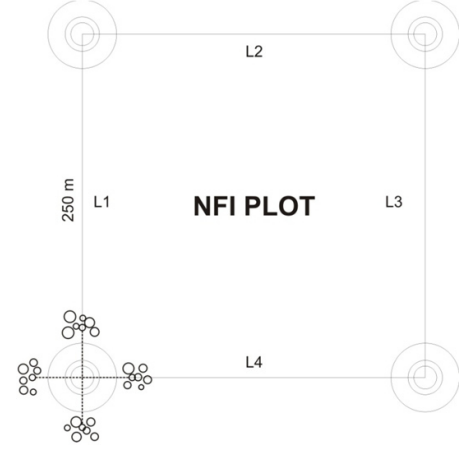

Fig. 6. Design of the uniform NFI and ICP large scale plots (FutMon large scale plot)

Research of an intensive nature in a nonsystematic survey network placed in representative forest ecosystems (level II), suitable for cause-effect relationship studies started in 1989 and developed in 1991 and 1992. Thirteen intensive permanent plots (IPP) were chosen in representative forest ecosystems near meteorological stations and were situated in historical impact zones subject to pollution and/or long recurrent droughts.

An IPP consists of five permanent sample plots (PSP) placed $30 \mathrm{~m}$ from each other in a crosswise direction in the cardinal directions from the plot center $(\mathrm{N}, \mathrm{E}, \mathrm{S}, \mathrm{W})$ and to the center of the plot. All five PSPs are placed in the 
same stand conditions and their land surface together with the IPP's buffer zone cover about 0.7 ha (Fig. 7).Until now, date related to: (i) crown condition using defoliation percentage (yearly); (ii) soil analysis (every 10 years); (iii) soil solution using lysimeter method (continuous); (iv) foliar analysis (every 2 years); (v) growth (permanent, continuous, every 5 years); (vi) atmospheric deposition in open field and under the canopy - bulk and throughfall (continuous); (vii) meteorology (continuous); (viii) ground vegetation (every 5 years); (ix) phenology (continuous); (x) air quality using passive samplers during the growing season and collocated ozone active monitor (continuous) and (xi) litterfall (continuous) have been collected.

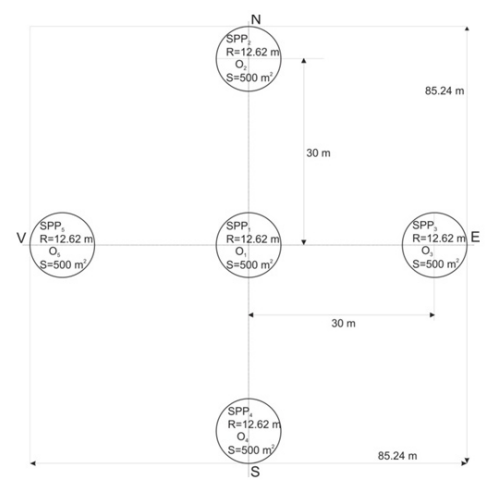

Fig. 7. Design of a Romanian intensive forest monitoring (level II) plot

The applied methodology followed the 1986, 1989, 1994 and 2010 versions of the ICP-Forests Manuals, the last one being revised during FutMon project period (2009-2011).

Statistical analyses of monitoring data were performed using Excel and SPSS software. Geospatial distribution of forest health status dynamics was achieved using ArcGis 9.2-Geostatistical software.

\section{Results}

The results on forest condition in Romania have been based on information collected from a national optimized network ( $4 \times 4 \mathrm{~km}$; or herein, the national grid system). The representativity error $(\mathrm{e} \%)$ was $\pm 1.02 \%(\mathrm{p}<0.05)$ (Badea, 1998), which is comparable with the ones calculated at European grid system level $(16 \times 16 \mathrm{~km})$ of $\mathrm{e} \%=$ $\pm 1.31 \%$ (Badea et al., 2005).

The European grid system plots placed in Romanian forests (about 252 permanent plots) are not representative of the forest conditions in Romania ( $\mathrm{e} \%>20 \%, \mathrm{p}>0.05)$ (Badea, 1998). Yet, it was noticed that the temporal trend of results dynamics could be compared with the more accurate ones recorded in the national grid system network.

By comparing the dynamics of the multiannual results at an "all species" level, one can observe considerable differences between the percentages of damaged trees (de- foliation $>25 \%$ ) recorded in both systems of plots (Fig. $8)$. In general, the maximum $(21.3 \%, 14.3 \%$ and $39.9 \%$, $36.5 \%$, respectively) and the minimum $(9.7 \%, 8.1 \%$ and $30.1 \%, 24.3 \%$, respectively) values were recorded in the same years (1994, 2000 and 1991, 2005 respectively); these were mainly believed to be an effect of precipitation deficits and high temperatures, respectively (Badea, 1998; Badea and Neagu, 2007). A similar situation was encountered at European grid system level for all species (Fig. 9).

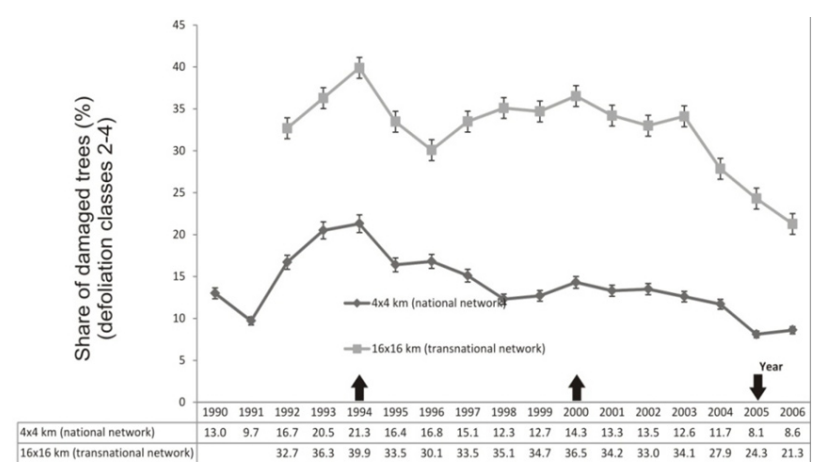

Fig. 8. Dynamics of forest health status in Romania (all species)

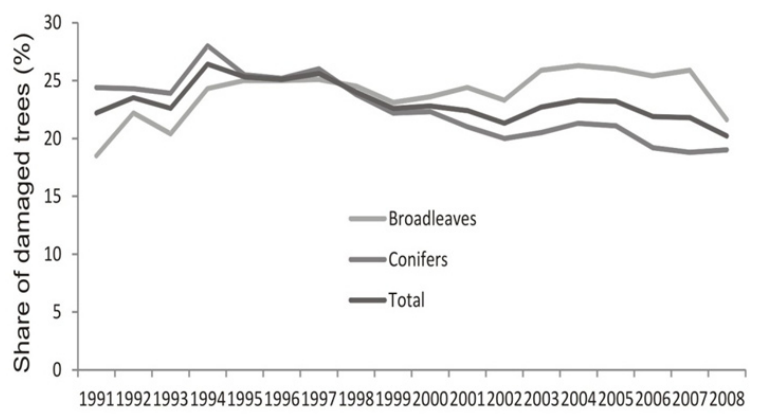

Year

Fig. 9. Dynamics of forest health status in Europe

Also, the dynamics of the percentage of damaged trees for each main group of species (conifer and broadleaf species) has followed almost the same trend in both networks (Fig. 10, 11).

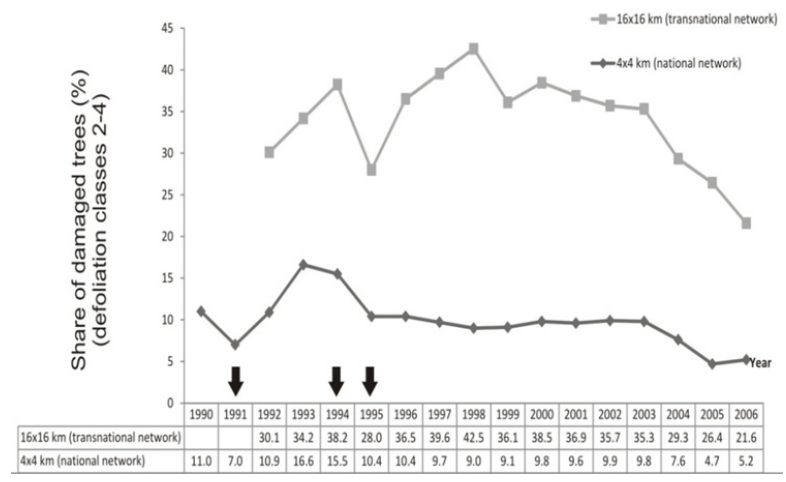

Fig. 10. Dynamics of forest health status in Romania (conifers) 
618

Individually, the main species (Picea abies, Abies alba, Fagus sylvatica, Quercus robur, Quercus petraea, Quercus pubescens + Quercus pedunculiflora, Robinia pseudoacacia) followed the same dynamics (Fig. 12). The highest and the lowest percentages of damaged trees were recorded at about the same time, with small deviations (1-2 years) depending on species reaction to the quantity of precipitation or to temperatures from the previous year (autumn season) or current year (spring and vegetation season) (Badea, 1998; Badea and Neagu, 2007).

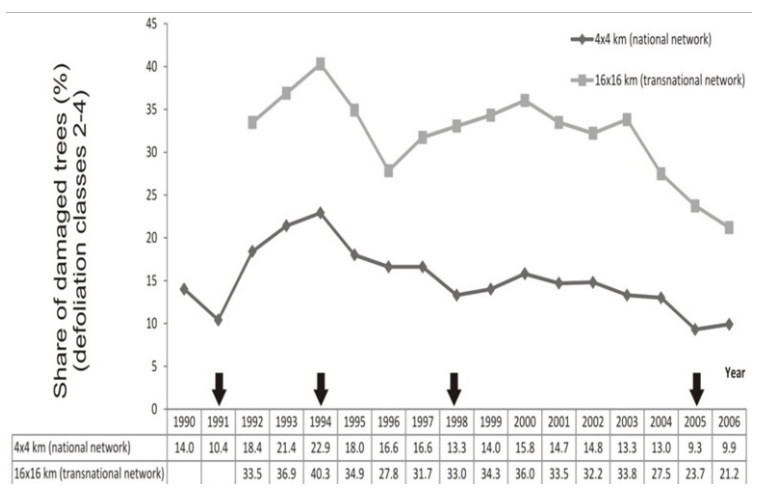

Fig. 11. Dynamics of forest health status in Romania (broadleaf species)

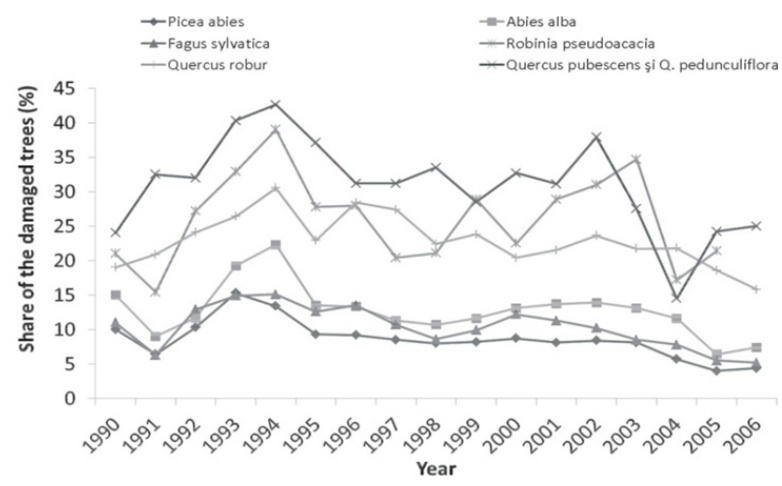

Fig. 12. Temporal trendline of forest health status dynamics in Romania during 1990-2006

By adjusting the multiannual variation (1991-2006) in the percentage of damaged trees (defoliation $>25 \%$ ) recorded in the two monitoring networks (the national and the European grid systems), it was noticed that the difference between temporal trend line slopes were not significant $(\mathrm{p}<0.05)$. The increasing/decreasing trends are insignificantly different. The linear slopes are practically the same (Fig. 13).

Univariate covariance analysis (ANCOVA) emphasized the differences recorded between national and $\mathrm{Eu}-$ ropean grid system networks. Therefore, without information from the national grid system we would be able to know the trend of forest health dynamics at the national level (especially because the national network was abandoned in 2008), taking into consideration only the results recorded in existing European grid system plots placed in Romanian forests.

The analysis of the correlation between the percentages of damaged trees recorded in the national network com-

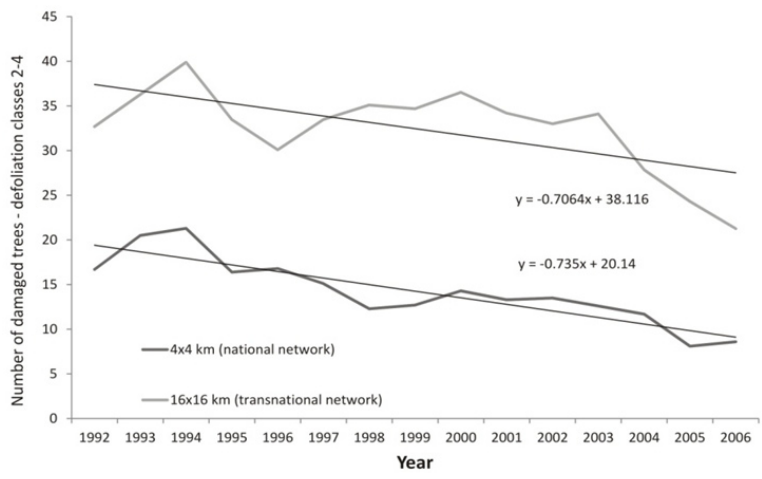

Fig. 13. Temporal trendline of forest health status dynamics in Romania, during 1990-2006

pared with those recorded in the European grid system network was significant $(r=0.74$ for all species, $r=0.79$ for broadleaf species and $r=0.47$ for conifers). The regression is represented by an exponential function, which may be used to estimate the intensity of forest damages with a lower accuracy (Fig. 14).

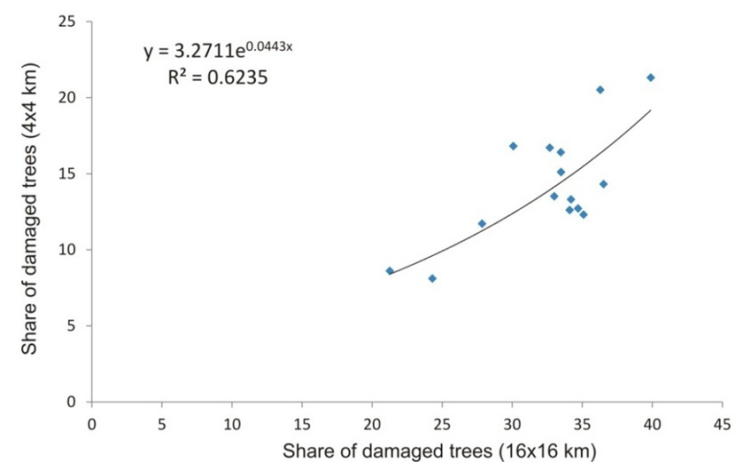

Fig. 14. Distribution of damaged trees (percent defoliation $>25 \%$ ) from the national grid system in relation to those registered in the European grid system (all species)

A similar situation, statistically confirmed, can also be observed for broadleaf species, which represents a high percentage (over 65\%) of the total number of assessed trees (Fig. 15a); the same situation is not statistically significant for conifers (Fig. 15b).

Comparing the adjusted values calculated for all species using these exponential functions, presently established based on experimental distribution (variation of multiannual percentages of damaged trees recorded in the national network), with the real values, no significant differences were found (texp $=0.335, p>0.05)$. So, from a statistical point of view, this type of pattern can be used to document the trend of Romanian forest health based on information from the European grid system network of 
plots. In this way, an image of the share of damaged trees values (adjusted) could be obtained (Fig. 16).

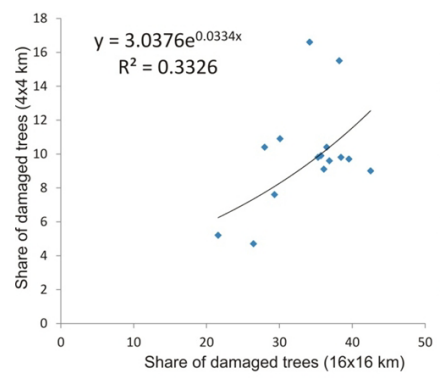

(a)

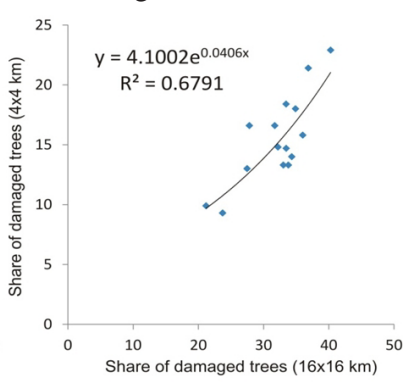

(b)
Fig. 15. Distribution of damaged trees (percent defoliation > $25 \%$ ) from the national grid system in relation to those registered in the European grid system (broadleaf species (a) conifers (b))

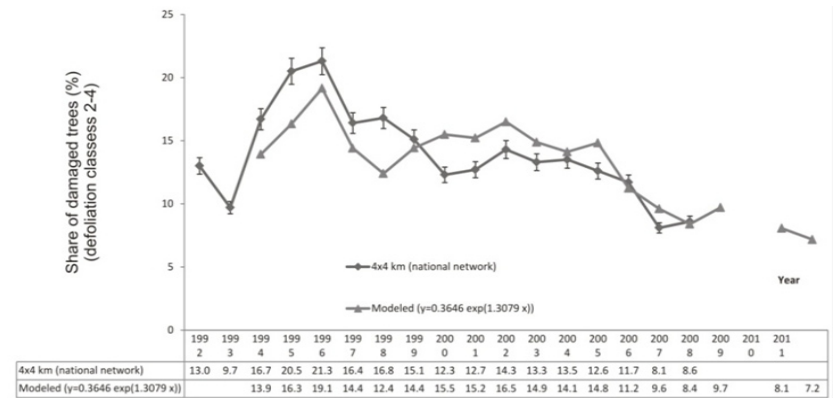

Fig. 16. Distribution of damaged trees (percent defoliation $>25 \%$ ) from the national grid system in relation to those registered in the European grid system (broadleaves)

Long term non-catastrophic damages highlighted by the annual tree mortality rates (\%) can alter forest structure and, consequently its functions (Allen et al., 2010). In Fig. 19 , only predominant, dominant and co-dominant trees are represented, which rules out incidence of tree mortality caused by competition. During 1992-2011, the annual mortality rates as a biological reaction of forest ecosystems to the damage occurring in the environment varied from 0.1 (in 1992) to 0.7 (in 1994), dramatically reaching maximum values with a delay of $1-2$ years after severe drought events such as occurred in 1994, 2000, 2005, 2009.

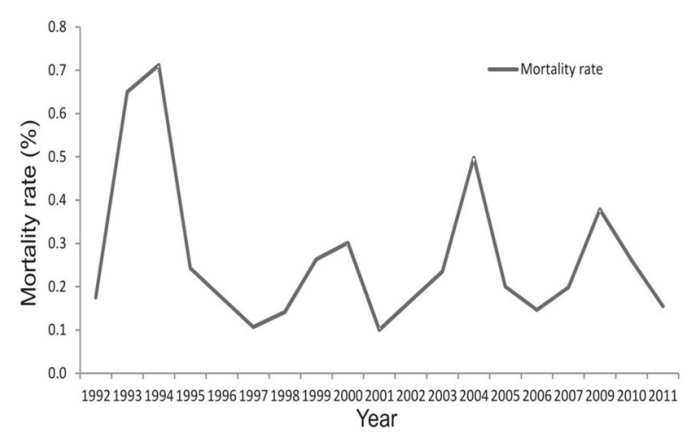

Fig. 17. Tree mortality as a biological reaction of forest ecosystems to the changing environment
Regional warming and consequent increases in water deficits are, most likely, the main contributors to the dynamics of this indicator, as well as to forest health status dynamics. One can observe that the main causes influencing forest health status since the year 1990 until the present day were represented mainly by air pollution combined with climate change effects, especially the precipitation deficit and extreme temperatures, and these phenomenons were more intense in the south and southeastern Romania (Fig. 18 a, b). Therefore, in those parts of Romania, during 1981-2010, in relation to the 1961-1990 reference period the temperature has raised as much as $0.7-0.8^{\circ} \mathrm{C}$ and the precipitation quantities dropped about $20-80 \mathrm{~mm}$. During the last decade (2001-2010), some recovery of precipitation rates $(37-60 \mathrm{~mm})$ was noticed compared with the same reference period (1961-1990) (Fig. 18 b).

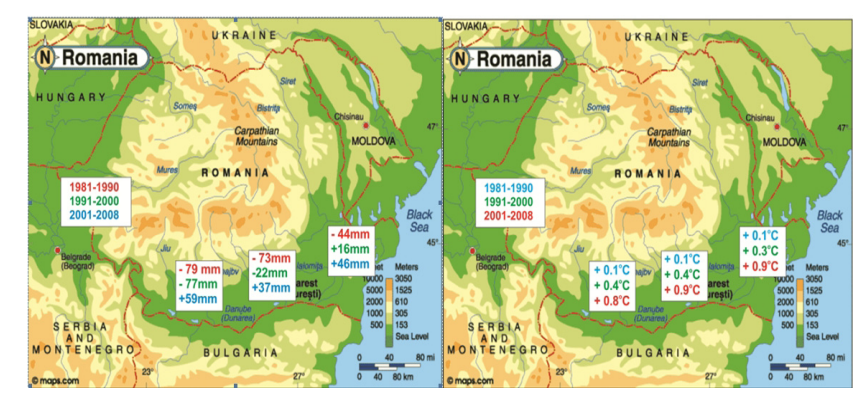

Fig. 18. The extent of climate change: (a) air temperature, (b) precipitation in southern and southeastern Romania during the last three decades (reference period 1961-1990)

As representative examples for the southern part of Romania, the data coming from two meteorological stations (Caracal and Alexandria) related to decennial dynamics of average air temperatures during 1961-2008 showed an obvious increasing trend since 1971 (around $1^{\circ} \mathrm{C}$ ) (Fig. 21 a, b). Also, we can observe a decreasing trend in precipitation quantity, beginning in 1981 and recovery during the last decade after 2001 (Fig. 22 a, b).

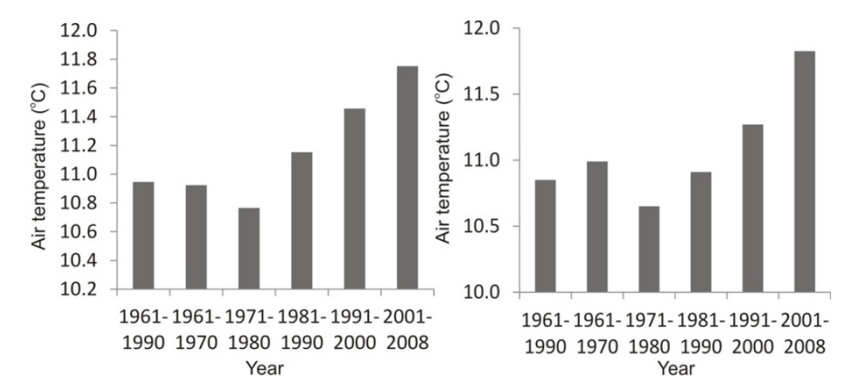

(a)

(b)

Fig. 19. Decennial dynamics of air temperature, during the 1961-2008 period at the Caracal (a) and Alexandria (b) meteorological stations in southern Romania 
620

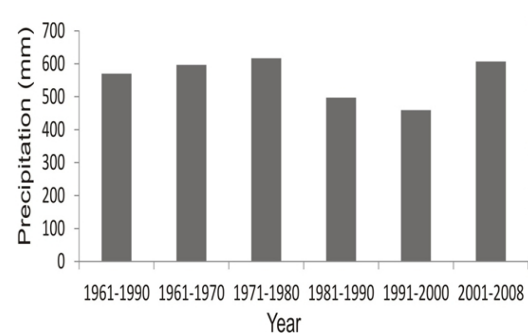

(a)

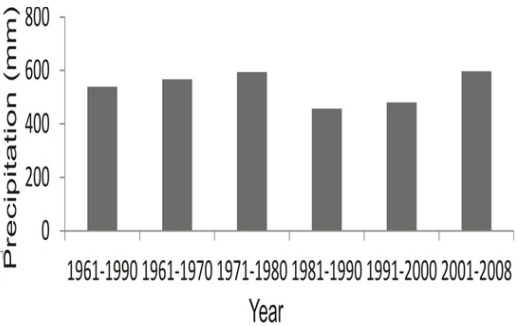

(b)

Fig. 20. Decennial dynamics of precipitation, during the 1961-2008 period at the Caracal (a) and Alexandria (b) meteorological stations in southern Romania
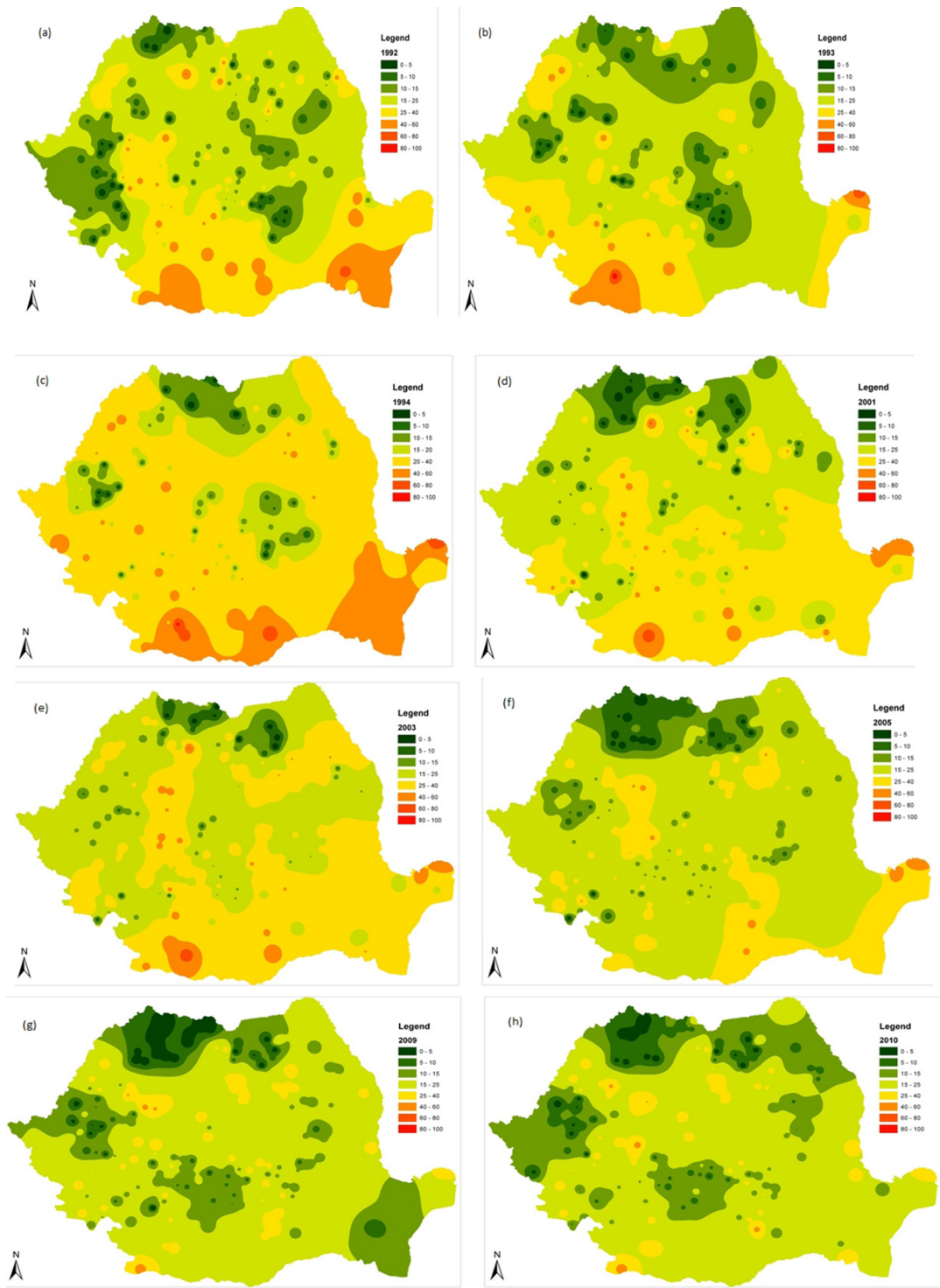

Fig. 21. Dynamics of the share of damaged trees (defoliation >25\%) in the European grid system during 1992 (a), 1993 (b), 1994 (c), 2001(d), 2003 (e), 2005 (f), 2009 (g) and 2010 (h)

These climatic conditions from south and southeastern Romania have had a very strong influence on forest health status of broadleaf species, especially, which are growing here and on the results for all species (broadleaf species being the majority, about $2 / 3$ of total number of trees assessed). 
A very good image of the influence of climatic conditions on dynamics of the damaged trees is given by results obtained during the period 1992-2001 (Fig. 21 a-e); the

high intensity of the tree damaging process could be correlated with increasing of temperatures during 19812010 (Fig. 22 a-c) and decreasing of precipitation during 1981-2000 (Fig. 22 d, e). A slight increase in the amount of precipitation was recorded starting with 2001 (Fig. 22 f).

The deterioration of forest health status continued into 2003, but after that an improving trend of forest health status was seen after 2005 (Fig. $21 \mathrm{f}-\mathrm{h}$ ). Regarding the assessment of biotic and abiotic damage factors, in the last three years (2009-2011), most of the observed damage symptoms were attributed to insects (12-16\%), abiotic factors (9-10\%), fungi (3-4\%) and anthropogenic factors (2-3\%) (Fig. 23) (Neagu et al., 2011).

The deterioration of forest health status continued into 2003, but after that an improving trend of forest health status was seen after 2005 (Fig. $21 \mathrm{f}-\mathrm{h}$ ). Regarding the assessment of biotic and abiotic damage factors, in the last three years (2009-2011), most of the observed damage symptoms were attributed to insects (12-16\%), abiotic factors (9-10\%), fungi (3-4\%) and anthropogenic factors (2-3\%) (Fig. 23) (Neagu et al., 2011).

Thus, high temperatures and low precipitation over long time periods, especially in southern and southeastern
Romania, directly influenced forest health in this region. At a national scale, the mean annual air temperature rose by $0.6{ }^{\circ} \mathrm{C}$ in the last 100 years (Fig. 24); the evolution by decades of mean multiannual air temperature from 1961 to 2010 show the average air temperature rose by $0.4-0.6$ ${ }^{\circ} \mathrm{C}$ during 2001-2010 when compared with every other decade. The increasing trend is obvious especially beginning with 1971 (Fig. 24).

In the Romanian intensive forest monitoring network (level II), but also in other Long Term Ecological Research sites (LTER), the results showed that the percent of damaged trees (defoliation $>25 \%$ ) is not influenced by the concentrations of monitored pollutants $\left(\mathrm{O}_{3}, \mathrm{NO}_{2}, \mathrm{NH}_{3}\right)$ (Bytnerowicz et al., 2005; Silaghi et al., 2011; Badea et al., 2012; Silaghi and Badea, 2012).

Ozone concentrations, higher than the phytotoxic level and with high levels of nitrogen and sulfur deposition, can have significant consequences on the health status and biodiversity of forest ecosystems, similar ones registered in other European countries (Bytnerowicz et al., 2002).

In general, in the Romanian monitoring networks (level II, LTER Retezat and LTER Bucegi-Piatra Craiului sites, Carpathian network), high ozone concentrations had no negative effect on forest health and tree growth. Also, specific ozone injuries weren't observed. However, the pollutant levels (Fowler et al., 1999) accompanied by the variation of climatic parameters through severe deficit
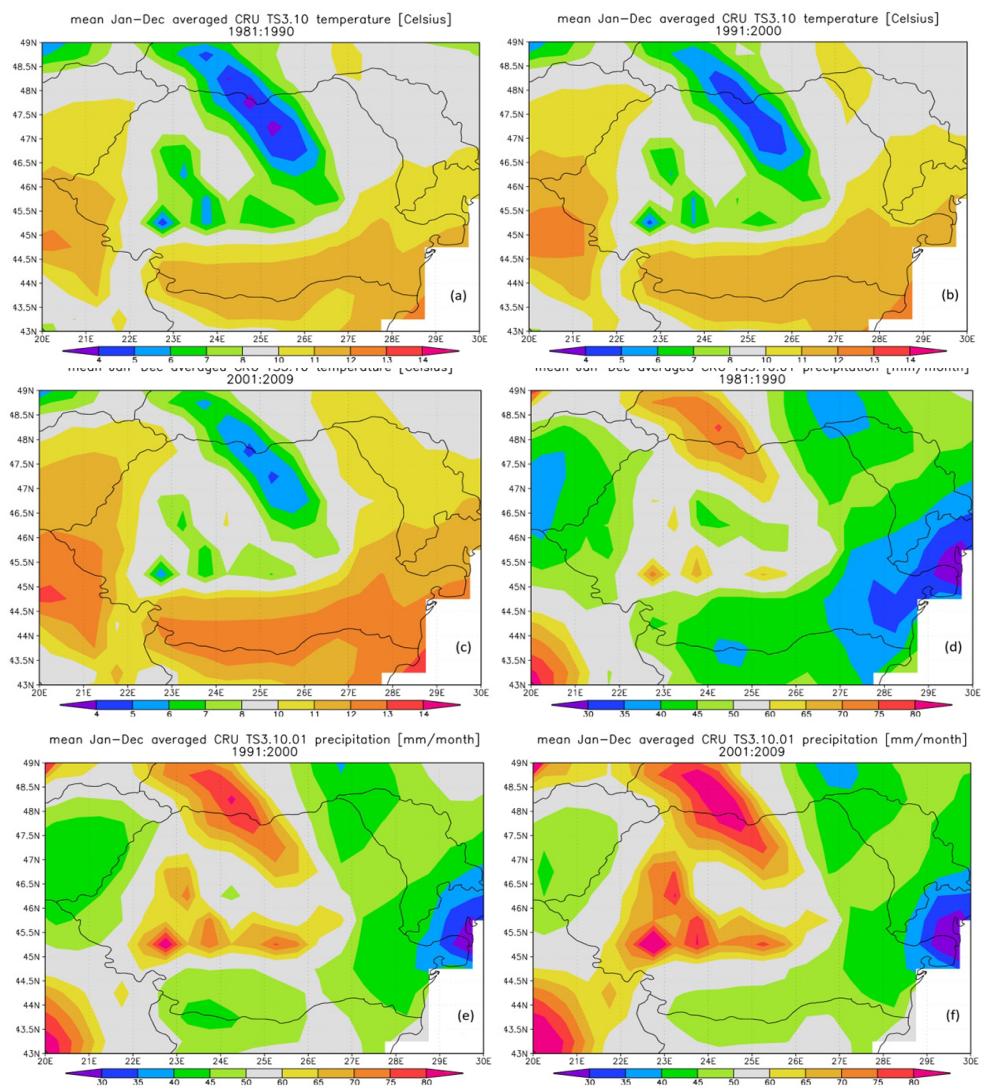

Fig. 22. Variation of average decennial temperatures (a, 1981-1990; b, 1991-2000; c, 2001-2009) and precipitation (d, 1981-1990; e, 1991-2000; f, 2001-2009) at the national level 
622

of precipitation and a considerable increase in temperatures (Bytnerowicz et al., 2008) can produce significant negative effects on forest health and the health of individual trees.

The quantitative and qualitative analysis of pollutants fluxes (atmospheric depositions) in the level II monitoring network and in the other forest LTER sites (LTER Retezat and LTER Bucegi - Piatra Craiului sites) showed that from 1998 to 2009 , the input of $\mathrm{S}_{-} \mathrm{SO}_{4}$ flux registered a slow tendency to decrease in in concentrations in both the open field (TL) and under the canopy (SC) (Fig. 25). In soil, the tendency is increasing, mainly at $10 \mathrm{~cm}$ and 40 $\mathrm{cm}$ depths with an accumulation of $\mathrm{S}_{-} \mathrm{SO}_{4}$ in the upper soil horizon from previous years. As for nitrate ions $\left(\mathrm{N}-\mathrm{NO}_{3}\right)$ the trend of decreasing concentrations is more obvious in the open field than under the canopy (Fig. 26).

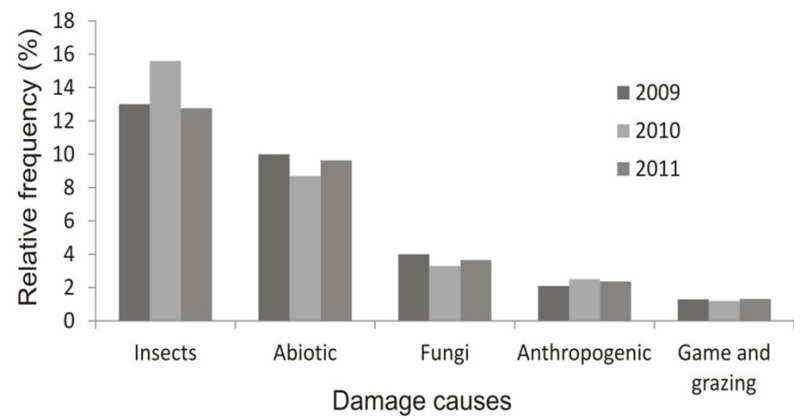

Fig. 23. Distribution of the most frequent causes of mechanical damage to trees

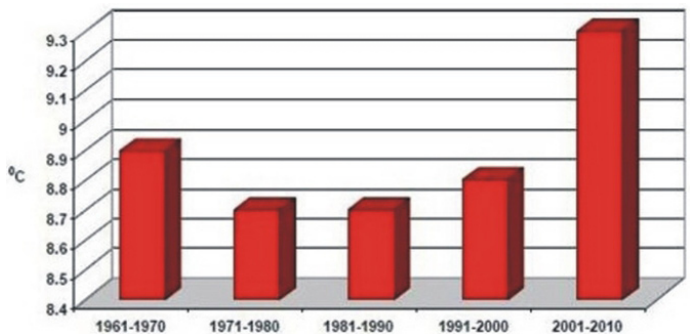

Fig. 24. Decennial evolution of mean multiannual air temperature: Romania (source Romanian National Administration for Meteorology)

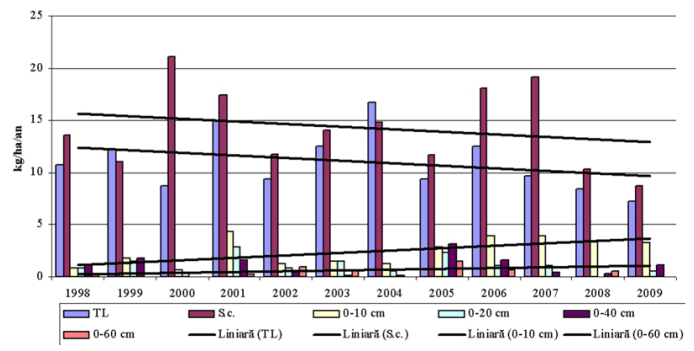

Fig. 25. Variability of the yearly flux of $\mathrm{S}-\mathrm{SO}_{4}\left(\mathrm{~kg} \mathrm{ha}^{-1} \mathrm{yr}^{-1}\right)$ at different levels in the ecosystem in a Mihaesti-sessile oak plot during 1998-2009
Both for open field (TL), under canopy (SC) and in soil depths, the ammonia (N-NH4) ions the fluxes show more variable tendencies. Until 2005, the fluxes increased (from 12 to $17 \mathrm{~kg} \mathrm{ha}^{-1} \mathrm{yr}^{-1}$ ), while after 2005 a clear tendency of reduction of flux (to $5 \mathrm{~kg} \mathrm{ha}^{-1} \mathrm{yr}^{-1}$ ) was recorded (Fig. 27).

The influence of $\mathrm{S}-\mathrm{SO}_{4}, \mathrm{~N}-\mathrm{NO}_{3}$ and $\mathrm{N}-\mathrm{NH}_{4}$ in the soil acidification is well known. The effects on the soil are different related to critical loads calculated on the basis of the soil substrate. For example, the comparisons of the mean flux of sulfur $\left(\mathrm{S}_{-} \mathrm{SO}_{4}\right)$ and nitrogen with the critical loads for two core plots from level II show that soil and forest from the Mihăeşti-sessile oak site are more exposed to acidification than the soils at the Fundata-European beech site where the soils and limestone are more resistant to acidification (Tab. 1).

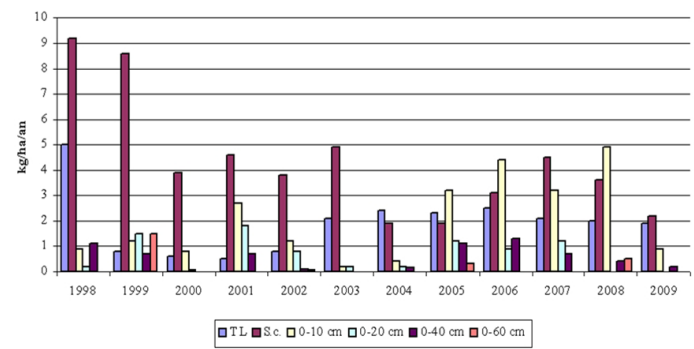

Fig. 26. Variability of the yearly flux of N-NO3 $\left(\mathrm{kg} \mathrm{ha}^{-1} \mathrm{yr}^{-1}\right)$ at different levels in the ecosystem in a Mihaesti-sessile oak plot during 1998-2009

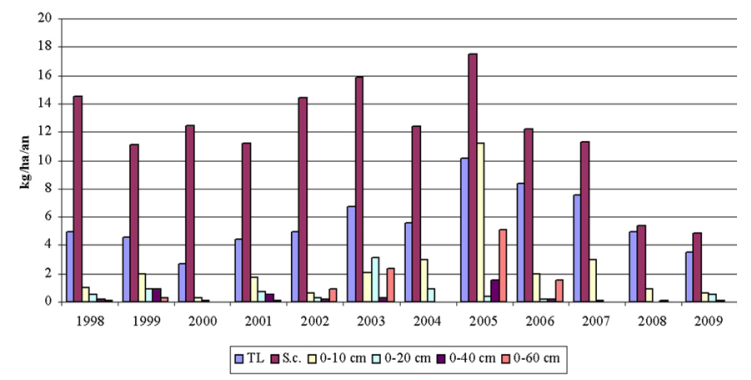

Fig. 27. Variability of the yearly flux of N-NH4 $\left(\mathrm{kg} \mathrm{ha}^{-1} \mathrm{yr}^{-1}\right)$ at different levels in the ecosystem in a Mihaesti-sessile oak plot during 1998-2009

Tab. 1. Critical loads for the level II core plots: Mihăieşti-sessile oak and Fundata-European beech

\begin{tabular}{|c|c|c|c|c|c|}
\hline \multirow[b]{2}{*}{ Plot } & \multirow{2}{*}{$\begin{array}{c}\text { Soil } \\
\text { substrate }\end{array}$} & \multicolumn{2}{|c|}{ Critical loads } & \multicolumn{2}{|c|}{ Mean flux registered } \\
\hline & & $\begin{array}{c}\mathrm{kg} \mathrm{S} \mathrm{S}^{*} \mathrm{a}^{-1} \\
\mathrm{yr}^{-1}\end{array}$ & $\begin{array}{c}\mathrm{kg} \mathrm{N} \mathrm{N}^{*} \mathrm{~h}^{-1} \\
\mathrm{yr}^{-1}\end{array}$ & $\begin{array}{c}\mathrm{kg} \mathrm{S}^{*} \mathrm{ha}^{-1} \\
\mathrm{yr}^{-1}\end{array}$ & $\begin{array}{c}\mathrm{kg} \mathrm{N}^{*} \mathrm{ha}^{-1} \\
\mathrm{yr}^{-1}\end{array}$ \\
\hline $\begin{array}{l}\text { Mihăeşti- } \\
\text { sessile oak }\end{array}$ & $\begin{array}{l}\text { Loessoid } \\
\text { deposits } \\
\text { and stony } \\
\text { deposits }\end{array}$ & $3-8$ & $15-20$ & 15 & 16 \\
\hline $\begin{array}{l}\text { Fundata- } \\
\text { European } \\
\text { beech }\end{array}$ & Limestone & $>32$ & $15-20$ & 11 & 8.5 \\
\hline
\end{tabular}


High frequencies of acidic and alkaline throughfall and of high $\mathrm{Ca}$ concentrations had negative effects on crown condition. The same negative effects can be produced by the high frequency of acid rain on the chemical composition of soils, which influence the physiologic processes of trees (Edzards et al., 1997; Bytnerowicz et al., 2005). The appearance of the acid rain events leads to soil acidification with negative effects on forest health (Badea et al., 2012).

\section{Conclusions}

After analyzing the Romanian forest monitoring systems, based on the results obtained through their implementation and functionality, the following conclusions can be made: a) over the years, environmental pollution was the main factor causing the decline of forest ecosystems but it is now accompanied by and experiencing cumulative effects with climate change and various biotic and abiotic factors; $b$ ) annual results obtained in the European grid system in Romania could be used to estimate the increasing/decreasing trend of forest health status compared to the previous years at the national level; c) in the last decade, Romanian forests were rated as experiencing low to medium levels of impact in the European hierarchy, based on percentage of damaged trees, with the overall forest health status experiencing a slight improvement; d) in southern and southeastern Romania, the forests are more frequently damaged by the climate changes, requiring special attention on this region which lies in the path of the Euro-Asian steppe expansion towards the west; e) air pollution and bulk deposition of pollutants in the forests and in the forest soils are an evident threat. Sulfur and nitrate deposition are a major concern related to forest ecosystems health and can lead to an increase in soil acidity; f) should the tropospheric ozone concentration exceed a critical threshold (40-50 ppb) this may have negative consequences on forest health and growth; g) rising temperatures and lower levels of precipitations may produce significant changes, e.g. a higher frequency of extreme events, drought, catastrophic weather events which have negative effects on forested ecosystems. The safest way to guarantee that the forests will be able to adapt to current and future climate change is to ensure the preservation of optimum forest biodiversity; h) maintaining an optimum state of forests and conserving this most important terrestrial resource requires high levels of scientific information accessible via a well-organized assessment, analysis and warning system such as the Forest Monitoring System.

\section{Acknowledgments}

We acknowledge the financial support from the $\mathrm{Eu}$ ropean Commission through LIFE+ program (FutMon) and COST Action FP0903, and the technical support from Romanian Public Authority for Forestry, ICP-Forests, National Forest Administration-ROMSILVA and National Administration for Meteorology. We also want to thank everyone on the forest monitoring team from ICAS for their work.

\section{References}

Allen CD, Macalady AK, Chenchouni H, Bachelet D, McDowell N, Vennetier M, Kitzberger T, Rigling A, Breshears DD, Hogg EH, Gonzales P, Fensham R, Zhang Z, Castro J, Demidova N, Lim JH, Allard G, Running SW, Semerci A, Cobb N (2010). A global overview of drought and heatinduced tree mortality reveals emerging climate change risks for forests. Forest Ecology and Management 259:660-684.

Allen CD, Breshears DD (1998). Drought-induced shift of a forest-woodland ecotone: rapid landscape response to climate variation. Proceedings of the National Academy of Sciences of the United States of America 95:14839-14842.

Badea O, Bytnerowicz A, Silaghi D, Neagu S, Barbu I, Iacoban C, Iacob C, Guiman G, Preda E, Seceleanu I, Oneata M, Dumitru I, Huber V, Iuncu H, Dinca L, Leca S, Taut I (2012). Status of the Southern Carpathian forests in the long-term ecological research network. Environmental Monitoring and Assessment 184(12):7491-7515.

Badea O, Neagu S (2007). Forest health status in Romania in 2006, evaluated using the national monitoring network ( $4 \times$ $4 \mathrm{~km}$ ). Revista Padurilor 5:11-17 (in Romanian).

Badea O, Tanase M, Patrascoiu N (2005). Forest health status in Romania in the climate change context. In: V. Giurgiu (Ed.) Silvology (127-137). Bucharest: Romanian Academy Ed (in Romanian).

Badea O (1998). Fundamente dendrometrice si auxologice pentru monitoringul forestier. PhD thesis, "Stefan cel Mare" University, Suceava (in Romanian).

Badea O, Patrascoiu N (1998). Forest condition in Romania (chapters 1, 2, 3-3.1, 4-4.1, 4.2, 4.3). Fontainbleau: ONF.

Badea O, Patrascoiu N (1992). Results on forest condition in Romania in 1991. CCE Report. UN/ECE, Bruxelles.

Bigler C, Gavin DG, Gunning C, Veblen TT (2007). Drought induces lagged tree mortality in a subalpine forest in the Rocky Mountains. Oikos 116:1983-1994.

Bytnerowicz A, Arbaugh M, Schilling S, Fraczek W, Alexander D (2008). Ozone distribution and phytotoxic potential in mixed conifer forests of the San Bernardino Mountains, southern California. Environmental Pollution 155:398408.

Bytnerowicz A, Badea O, Popescu F, Musselman R, Tanase M, Barbu I, Fraczek W, Geambasu N, Surdu A, Danescu F, Postelnicu D, Cenusa R, Vasile C (2005). Air pollution, precipitation chemistry and forest health in the Retezat Mountains, Southern Carpathians, Romania. Environmental Pollution 137:546-567.

Bytnerowicz A, Godzik B, Fraczek W, Grodzinska K, Krywult M, Badea O, Barancok P, Blum O, Cerny M, Godzik S, Mankovska B, Manning W, Moravcik P, Musselman R, Oszlanyi J, Postelnicu D, Szdzuj J, Varsavova M, Zota M 
624

(2002). Distribution of ozone and other air pollutants in forests of the Carpathian Mountains in central Europe. Environmental Pollution 116:3-25.

Carnicer J, Coll M, Ninyerola M, Pons X, Sánchez G, Peñuelas J (2011). Widespread crown condition decline, food web disruption, and amplified tree mortality with increased climate change-type drought. Proceedings of National Academy of Science of the United States of America 108(4):1474-1478.

Ciais P, Reichstein M, Viovy N, Granier A, Ogee J, Allard V, Aubinet M, Buchmann N, Bernhofer Chr, Carrara A, Chevallier F, De Noblet N, Friend AD, Friedlingstein P, Grunwald T, Heinesch B, Keronen P, Knohl A, Krinner G, Loustau D, Manca G, Matteucci G, Miglietta F, Ourcival JM, Papale D, Pilegaard K, Rambal S, Seufert G, Soussana JF, Sanz MJ, Schulze ED, Vesala T, Valentini R (2005). Europe-wide reduction in primary productivity caused by heat and drought in 2003. Nature 437:529-533.

Edzards C, De Vries W, Erisman J (1997). Ten years of monitoring forest condition in Europe. PCC of ICP Forests. UN/ ECE.

Fowler D, Cape JN, Coyle M, Flechard C, Kuylenstierna J, Hicks K, Derwent D, Johnson C, Stevenson D (1999). The global exposure of forests to air pollutants. Water Air and Soil Pollution 116:5-32.

Giurgiu V (1988). Management of forests with multiple functions. Ed. Ceres, Bucharest (In Romanian).

Giurgiu V (1979). Forest dendrometry and auxology. Ed. Ceres, Bucharest (in Romanian).

Granier A, Reichstein M, Breda N, Janssens I A, Falge E, Ciais P, Grunwald T, Aubinet M, Berbigier P, Bernhofer C, Buchmann N, Facini O, Grassi G, Heinesch B, Ilvesniemi H, Keronen P, Knohl A, Kostner B, Lagergren F, Lindroth A, Longdoz B, Loustau D, Mateus J, Montagnani L, Nys C, Moors E, Papale D, Peiffer M, Pilegaard K, Pita G, Pumpanen J, Rambal S, Rebmann C, Rodrigues A, Seufert G, Tenhunen J, Vesala T, Wang Q (2007). Evidence for soil water control on carbon and water dynamics in European forests during the extremely dry year: 2003. Agricultural and Forest Meteorology 143:123-145.

Ianculescu M (1990). Cercetări privind dinamica cresterilor și evaluarea pagubelor la arboreta aflate sub influența poluării industrial pe grade de vătămare. Bucharest: ICAS (personal communication) (in Romanian).

IPCC (2007). Climate change 2007: the physical science basis. In: Solomon S, Qin D, Manning M, Chen Z, Marquis M, Averyt KB, Tignor M, Miller HL (Eds.). Contribution of Working Group I to the Fourth Assessment. Report of the Intergovernmental Panel on Climate Change. Cambridge University Press, Cambridge, United Kingdom/New York, NY, USA, 996 pp.

Jentsch A, Kreylingn J, Beierkuhnlein C (2007). A new generation of climate change experiments: events, not trends. Frontiers in Ecology and the Environment 5:365-374.

Lindner M, Maroschek M, Netherer S, Kremer A, Barbati A,
Garcia-Gonzalo J, Rupert Seidl R, Delzon S, Corona P, Kolstroma M, Lexer MJ, Marchetti M (2010). Climate change impacts, adaptive capacity, and vulnerability of European forest ecosystems. Forest Ecology and Management 259:698-709.

Lorenz M (1991). Interim report on cause-effect relationship in forest decline. ICP Forests, UNEP/CEE.

Neagu S, Badea O, Chira D, Nețoiu C, Olenici N, Silaghi D, Leca $S$ (2011). Crown condition on the intensive monitoring network during 2009-2010 period. Revista Pădurilor, 126(3-4):21-27 (in Romanian).

Patrascoiu N, Badea O (1990). Technical guidelines for forest health status assessment in Romania. Bucharest: ICAS Manuscript (in Romanian).

Piovesan G, Biondi F, Di Filippo A, Alessandrini A, Maugeris M (2008). Drought-driven growth reduction in old beech (Fagus sylvatica L.) forests of the central Apennines, Italy. Global Change Biology 14:1-17.

Silaghi D, Badea O (2012). Monitoring of ozone in selected forest ecosystems in Southern Carpathian and Romanian Intensive Monitoring Network (level II). Journal of Environmental Monitoring 14:1710-1717.

Silaghi D, Badea O, Neagu S, Leca S (2011). Air pollutants concentrations $\left(\mathrm{O}_{3}, \mathrm{NO}_{2}\right.$ and $\left.\mathrm{NH}_{3}\right)$ registered in selected forest ecosystems (core plots) in the Romanian Intensive Monitoring Network (Level II). Revista Pădurilor 126(3-4):85-92 (in Romanian).

Sterl A, Severijns C, Dijkstra H, Hazeleger W, van Oldenborgh GJ, van den Broeke M, Burgers G, van den Hurk B, van Leeuwen P J, van Velthoven P (2008). When can we expect extremely high surface temperatures? Geophysical Research Letters 35:L14703.

Stott PA, Stone DA, Allen MR (2004). Human contribution to the European heatwave of 2003. Nature 432:610-614.

Symeonides C (1979). Tree-ring analysis for tracing the history of pollution: Application to a study in northern Sweden. Journal of Environmental Quality 8(4):482-486.

Thimonier A, Pannatier EG, Schmitt M, Waldner P, Walthert L, Schleppi P, Dobbertin M, Krauchi N (2010). Does exceeding the critical loads for nitrogen alter nitrate leaching, the nutrient status of trees and their crown condition at Swiss Long-term Forest Ecosystem Research (LWF) sites? European Journal of Forest Research 129:443-461.

Thompson MA (1981). Tree rings and air pollution. A case study of Pinus monophylla growing in the east-central Nevada. Environmental Pollution (Series A) 26:251-266.

UN/ECE (2004). Manual on methods and criteria for harmonized sampling, assessment, monitoring and analysis of the effects of air pollution on forests. UN/ECE, ICP Forests, Hamburg. ISBN: 978-3-926301-03-1.

UN/ECE, CEC (1998). Forest Condition in Europe. Report on the 1997 Survey. Geneva, Brussels, 180p., ISSN 10203729. 
UN/ECE, CEC (1997). Forest Condition in Europe. Report on the 1996 Survey. Geneva, Brussels, 160p., ISSN 10203729.

UN/ECE, CEC (1996). Forest Condition in Europe. Report on the 1995 Survey. Geneva, Brussels, 212p., ISSN 10203729.

UN/ECE, CEC (1995). Forest Condition in Europe. Report on the 1994 Survey. Geneva, Brussels, 191p., ISSN 10203729.

UN/ECE, CEC (1994). Forest Condition in Europe. Report on the 1993 Survey. Geneva, Brussels, 173p.
UN/ECE, CEC (1993). Forest Condition in Europe. Report on the 1992 Survey. Geneva, Brussels, 156p.

UN/ECE, CEC (1992). Forest Condition in Europe. Report on the 1991 Survey. Geneva, Brussels, 117p.

UN/ECE (1989). Manual on methods and criteria for harmonized sampling, assessment, monitoring and analysis of the effects of air pollution on forests. UN/ECE, ICP Forests, Hamburg. ISBN: 978-3-926301-03-1.

UN/ECE (1979). Convention on Long-Range Transboundary Air Pollution. Geneva.

Vins B, Mrkva R (1973). Tree diameter increment losses of pine stands as a result of injurious emissions. Acta Universitatis Agriculturae, Brno, Series C (Fac Silv) 42:25-46.

Volz A, Kley D (1988). Evaluation of the Montsouris series of ozone measurements made in the nineteenth century. $\mathrm{Na}$ ture 332:240-242. 